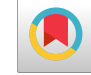

\title{
Association of Maternal Dietary Components During Pregnancy and/or Lactation with Insulin-Dependent Diabetes Mellitus
}

\author{
Shadi Salek ${ }^{1,2}$, Mahin Hashemipour ${ }^{1,3,{ }^{*}}$, Awat Feizi ${ }^{4}$, Silva Hovsepian ${ }^{2,5}$ and Roya Kelishadi ${ }^{2}$ \\ ${ }^{1}$ Isfahan Endocrine and Metabolism Research Center, Imam Hossien Children's Hospital, Isfahan University of Medical Sciences, Isfahan, Iran \\ ${ }^{2}$ Pediatrics Department, Child Growth and Development Research Center, Research Institute for Primordial Prevention of Non-Communicable Disease, Isfahan University of \\ Medical Sciences, Isfahan, Iran \\ ${ }^{3}$ Metabolic Liver Diseases Research Center, Imam Hossien Children's Hospital, Isfahan University of Medical Sciences, Isfahan, Iran \\ ${ }^{4}$ Department of Biostatistics and Epidemiology, School of Public Health, Isfahan University of Medical Sciences, Isfahan, Iran \\ ${ }^{5}$ Imam Hossein Children's Hospital, Isfahan University of Medical Sciences, Isfahan, Iran \\ "Corresponding author: Metabolic Liver Diseases Research Center, Isfahan Endocrine and Metabolism Research Center, Imam Hossien Children's Hospital, Isfahan University \\ of Medical Sciences, Isfahan, Iran. Email: hashemipour@med.mui.ac.ir
}

Received 2019 June 09; Revised 2020 May 09; Accepted 2020 May 27.

\begin{abstract}
Context: Considering the increasing trend in the incidence of type 1 diabetes mellitus (T1DM), the identification of its environmental determinants, especially those related to the prenatal and lactation period, might ultimately result in primary prevention of the disease. We aimed to review the evidence of the association between mothers' dietary components during pregnancy and/or lactation with T1DM.

Evidence Acquisition: An electronic and comprehensive literature search was performed until August 2019 in the international databases, including Web of Science (ISI), PubMed, and Scopus, using the following keywords: type 1 diabetes mellitus, autoimmunity, mother, maternal, diet and lactation in different combinations. Papers related to the objectives of the study were selected.

Results: Based on our review, the maternal consumption of meat, especially processed meat, was associated with increased risk of T1DM, whereas the maternal use of vegetables, potato, low-fat margarine, and berries showed protective effects against the development of T1DM in offspring. There was no significant association between the use of multivitamins and mineral supplements with T1DM, according to the available data. The results of the reviewed studies regarding the association between the maternal use of vitamin D, fatty acids, and coffee during pregnancy with T1DM were not consistent and conclusive.

Conclusions: Findings of this review indicate that the maternal consumption of some foods is associated with increased or decreased risk of T1DM. However, for some foods or dietary components, including coffee, vitamin D, and fatty acids, the results are not conclusive. We conclude that although maternal diet could influence the development of insulin autoantibodies (IA) and T1DM in offspring, there is no sufficient evidence for most nutrients, and available data are controversial, which should be dealt with in future cohort or interventional studies.
\end{abstract}

Keywords: Type 1 Diabetes, Diet, Mother, Lactation, Pregnancy

\section{Context}

Type 1 diabetes mellitus (T1DM) is an autoimmune disease resulting from a complex interaction between the immune system and environmental factors in individuals with genetic susceptibility (1). The incidence of T1DM has increased worldwide in the last decades (2).

Although T1DM has a strong genetic background and different loci are related to the disease, pieces of evidence such as the concordance of T1DM only in 30\% - 40\% of identical twins support the idea that genetic susceptibility is not the only contributor to the disease. This emphasizes the role of lifestyle and environmental factors in the pathogenesis of T1DM $(3,4)$. Based on the Eisenbarth proposed model, autoimmunity development, and beta-cell destruction, which result in T1DM, are triggered after exposure to some environmental factors in genetically susceptible individuals (5).

Moreover, some evidence indicates that environmental factors could explain the increasing trend of the disease in the last decades $(6,7)$. The increased rate of the disease in populations moving from low-incidence to high-incidence regions, the increased rate of T1DM in all age groups, and the earliest onset of the disease and greatest increasing trend of the disease in low-incidence regions are evidences, supporting the role of environmental factors in this context $(6,7)$. 
According to the "early life programming", exposure to some environmental risk factors during pregnancy could impose adverse effects on fetal development and causes chronic or degenerative diseases later in life (8). The roles of different environmental factors, including viruses, chemicals, and nutrition, in the pathogenesis of T1DM have been reported in several epidemiological studies (911). Some documents suggest that the role of nutrition is more prominent than the role of the other mentioned risk factors in the pathogenesis of T1DM (12). Accordingly, some maternal dietary nutritional elements during the pregnancy and lactation period, such as high-energy/highfat diets and high content of essential fatty acids, can play roles in the development of insulitis and T1DM (12). There is evidence of the role of some nutrients during the prenatal and lactation period, such as vitamins D and C, polyunsaturated fatty acids, and cow's milk protein, in the pathogenesis of T1DM; however, the findings of studies in this field are controversial and non-conclusive (13).

Considering the increasing trend of T1DM, the identification of its environmental determinants, especially those related to the prenatal and lactation period, might ultimately result in primary prevention of the disease. So far, few environmental risk factors have been reported to play a role in this regard. Therefore, we aimed to review the evidence of the association between maternal dietary components during pregnancy and/or lactation with T1DM in children. The objective was to summarize available data in the field and identify suggested high-risk nutrients or dietary components associated with the occurrence of T1DM. Our findings will be useful for designing further preventative strategies.

\section{Evidence Acquisition}

This review was conducted to determine the association of maternal dietary components during pregnancy and lactation with insulin-dependent diabetes mellitus. The Regional Ethics Committee of the Isfahan University of Medical Sciences approved the protocol of the study.

A search of the published literature was conducted in PubMed, Scopus, and Web of Science (ISI) until August 2019 using the following medical subject heading (MeSH) terms: [("type 1 diabetes mellitus" OR "autoimmunity") AND ("mother" OR "maternal") AND (diet) AND (lactation)]. The searches were limited to human studies without language and time limitations.

In the first step, the titles of all the retrieved papers were reviewed by two researchers. The inclusion criteria were human studies with the cohort, cross-sectional, and case-control designs, in which maternal nutrient consumption during pregnancy and lactation was an indepen- dent variable, and T1DM or insulin autoantibodies (IA) was the outcome. Duplicated and irrelevant papers were excluded.

In the second step, the reviewers selected final papers after two phases of titles/abstracts and full text screening. The selected full texts of the papers were carefully read by the researchers.

In addition, a manual search was performed in the reference lists of the selected full texts.

Data were extracted separately for cohort and casecontrol studies. For the cohort studies, the following data were extracted: authors, time and place of study, duration of follow up, sample size, studied dietary component, and final findings.

For the case-control studies, the following data were extracted: authors, time and place of study, sample size, studied dietary component, and final findings.

\section{Results}

In this review, 94 papers (PubMed: 38; Scopus: 39; and ISI:17) were identified through an electronic database search. Finally, 19 qualified articles (14-32) were selected for the final evaluation (Figure 1).

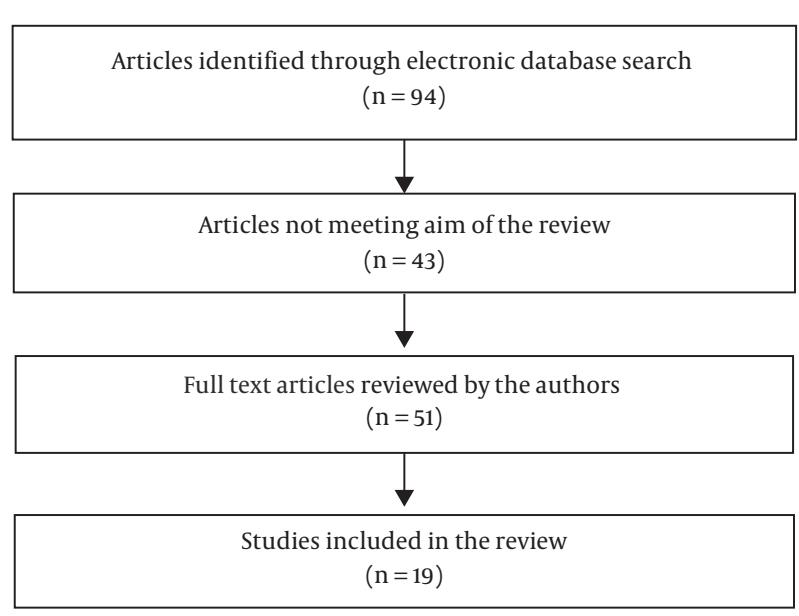

Figure 1. The flowchart of the study selection

Of the 19 selected studies, seven (14-20) were casecontrol studies and 12 (21-32) were cohort studies (Tables 1 and 2).

Eleven studies evaluated the association of different nutrients with T1DM (14-19, 29-32), and ten studies investigated the association of different nutrients with beta cell autoimmunity (21-29, 32). Only two studies assessed the association between different nutrients and T1DM during the lactation period $(19,29)$. 


\begin{tabular}{|c|c|c|c|c|c|}
\hline & Authors, Time, Place & Sample Size & Dietary Component & Outcome T1DM/IA & Findings \\
\hline $\mathbf{1}$ & $\begin{array}{l}\text { Virtanen et al., 1994, Finland } \\
\text { (14) }\end{array}$ & $\begin{array}{l}600 \text { newly diagnosed diabetic } \\
\text { children and } 536 \text { healthy } \\
\text { children as the control group } \\
\text { and their parents }\end{array}$ & Daily coffee or tea use & T1DM & $\begin{array}{l}\text { Maternal coffee consumption } \\
\text { during pregnancy did not } \\
\text { affect the risk of T1DM. }\end{array}$ \\
\hline 2 & Stene et al., 2000, Norway (15) & $\begin{array}{l}85 \text { diabetic subjects and 1,071 } \\
\text { control subjects }\end{array}$ & $\begin{array}{l}\text { Using multivitamin } \\
\text { supplements and cod liver oil }\end{array}$ & T1DM & $\begin{array}{l}\text { Using cod liver oil by pregnant } \\
\text { women was associated with } \\
\text { lower risk of T1DM in their } \\
\text { children }(\mathrm{OR}=0.3,95 \% \text { CL: } 0.12 \text { - } \\
0.75, \mathrm{P}=0.01) \text {. There was no } \\
\text { significant association } \\
\text { between the use of } \\
\text { multivitamin supplements by } \\
\text { pregnant women and the risk } \\
\text { of T1DM (OR }=1.11,95 \% \text { CL:0.69- } \\
\text { 1.77). }\end{array}$ \\
\hline 3 & Stene et al., 2003, Norway (16) & $\begin{array}{l}\text { 545T1DM children and } 1668 \\
\text { controls }\end{array}$ & $\begin{array}{l}\text { Using cod liver oil and/or } \\
\text { vitamin D supplements }\end{array}$ & T1DM & $\begin{array}{l}\text { There was no significant } \\
\text { association between cod liver } \\
\text { oil (OR=1.00, } 95 \% \text { CL: } 0.74 \text { - } \\
1.55) \text { and/or vitamin D } \\
\text { supplement }(\mathrm{OR}=0.98,95 \% \mathrm{CL} \text { : } \\
0.73 \text { - } 1.31) \text { consumption by } \\
\text { pregnant women with the risk } \\
\text { of T1DM }\end{array}$ \\
\hline 4 & Sipetic et al., 2005, Serbia (17) & $\begin{array}{l}105 \text { newly onset diabetic } \\
\text { children and } 210 \text { controls }\end{array}$ & $\begin{array}{l}\text { Consumption of } \\
\text { nitrosamine-rich food, } \\
\text { consumption of coffee, } \\
\text { coca-cola, and alcohol }\end{array}$ & T1DM & $\begin{array}{l}\text { The frequency of coffee, } \\
\text { coca-cola, nitrosamine-rich } \\
\text { foods, and alcohol } \\
\text { consumption was significantly } \\
\text { higher during pregnancy in } \\
\text { mothers of T1DM children }(\mathrm{P}< \\
0.05) \text {. Based on multivariate } \\
\text { regression analysis, there was a } \\
\text { significant association } \\
\text { between the consumption of } \\
\text { nitrosamine-rich foods by } \\
\text { mothers and T1DM (OR = 4.33, } \\
1.95-9.61, \mathrm{P}=0.001) \text {. }\end{array}$ \\
\hline 5 & $\begin{array}{l}\text { Sorensen et al., 2012, Norway } \\
\text { (18) }\end{array}$ & $\begin{array}{l}89 \text { mothers of T1DM children } \\
\text { and } 125 \text { mothers without T1DM } \\
\text { children }\end{array}$ & $\begin{array}{l}\text { Serum long chain n-3 fatty } \\
\text { acids including } \\
\text { eicosapentaenoic acid (EPA) or } \\
\text { docosahexaenoic acid (DHA) in } \\
\text { pregnant mothers }\end{array}$ & T1DM & $\begin{array}{l}\text { They did not report any } \\
\text { significant association } \\
\text { between the maternal serum } \\
\text { level of EPA (OR }=0.75 \text { for } \\
\text { upper vs. lower quartile, CL: } \\
0.34-1.65 \text { ) or DHA (OR = 0.71, } \\
\text { CL: } 0.33-1.53 \text { ) with the risk of } \\
\text { T1DM in their children. P for } \\
\text { trend was } 0.4 \text { and } 0.6 \text { for EPA } \\
\text { and DHA, respectively. }\end{array}$ \\
\hline 6 & Muntoni et al., 2015, Italy (19) & $\begin{array}{l}145 \text { T1DM children and } 153 \\
\text { controls }\end{array}$ & $\begin{array}{l}\text { Vegetables, meat, lipids, fruits, } \\
\text { fish, dairy products, cereals, } \\
\text { carbohydrates, beverages, and } \\
\text { alcohol }\end{array}$ & T1DM & $\begin{array}{l}\text { Different food groups did not } \\
\text { show statistical significance. } \\
\text { There was a trend toward } \\
\text { significance for meat } \\
\text { consumption during } \\
\text { pregnancy and lactation (P = } \\
0.059 \text {; OR = 0.318; 95\% CL: } 0.097 \\
-1.043 \text { ) }\end{array}$ \\
\hline 7 & $\begin{array}{l}\text { Thorsen et al., 2019, Denmark } \\
(20)\end{array}$ & 257 children with T1DM & $\begin{array}{l}\text { Maternal pure iron } \\
\text { supplementation }\end{array}$ & T1DM & $\begin{array}{l}\text { Iron supplementation } \\
\text { consumption by mothers } \\
\text { during pregnancy was not } \\
\text { associated with the risk of } \\
\text { T1DM in offspring }(\mathrm{HR}=1.05 \text {, } \\
\text { 95\% CI: } 0.76-1.45) \text {. }\end{array}$ \\
\hline
\end{tabular}

Abbreviations: T1DM, type 1 diabetes mellitus; OR, odds ratio; CI, confidence interval.

The most studied nutrient was vitamin $\mathrm{D}$ in foods or as a supplement $(16,21,22,26,30,32)$, and its association with T1DM was evaluated in six studies (one case-control and five cohort studies). Two of the cohort studies reported the protective role of vitamin $\mathrm{D}$ consumption by pregnant women for islet autoimmunity $(21,22)$. One of the studies 
only the protective effect of vitamin D in islet autoimmunity for in foods and not for supplementary vitamin $\mathrm{D}(21)$. The remaining studies did not show any significant association between maternal vitamin D use and T1DM or islet cell autoimmunity $(16,26,30,32)$.

Coffee was the second most studied dietary component $(14,17,25,27)$. The findings of four of the studies about coffee were not consistent. Accordingly, two of the studies reported an association between coffee consumption and $\operatorname{T1DM}(17,25)$, one of them did not show any association in this regard (14), and another one of them reported a protective effect of coffee against T1DM during pregnancy (27).

Four of the studies investigated the association between the maternal intake of different types of fatty acids (SFA, MUFA, and PUFA) during pregnancy and the risk of $\operatorname{T1DM}(18,28,29,32)$. Most of the evaluations did not show any significant association between the maternal intake of different fatty acids during pregnancy and T1DM. One of the studies reported a negative association between palmitic acid (MUFA) in foods and the risk of T1DM (28). Another one of the studies showed no association between maternal fatty acid use during lactation and the risk of $\operatorname{T1DM}(29)$.

Two of the studies did not demonstrate any association between the maternal intake of retinol, beta-carotene, vitamin C, vitamin E, selenium, zinc, manganese, iron, and multivitamin with T1DM or beta-cell autoimmunity $(15,24)$. One of the studies revealed an insignificant association between maternal iron supplementation use and the risk of $\operatorname{T1DM}(20)$.

Two of the studies reported that the maternal consumption of meat, especially processed meat, was associated with an increased risk of T1DM or beta-cell autoimmunity $(19,29)$. Two recent studies indicated that using meat by mothers during lactation could increase the risk of T1DM in offspring $(19,29)$.

One recent study reported that higher glutencontaining foods during pregnancy was associated with an increased risk of T1DM (31).

\section{Discussion}

In this study, we reviewed studies investigating the association between maternal diet during pregnancy and/or lactation with T1DM or beta-cell autoimmunity. Based on our review, the maternal consumption of meat, especially processed meat, was associated with increased risk of T1DM, whereas the maternal use of vegetables, potato, lowfat margarine, and berries had a protective role in the development of T1DM in offspring. There was no significant association between the use of multivitamins and mineral supplements with T1DM, according to the available data.
The results of the reviewed studies regarding the association between the maternal use of vitamin D, fatty acids, and coffee during pregnancy with T1DM were not consistent and conclusive.

As previously mentioned, T1DM results from insulin deficiency, mainly due to insulitis. Many studies suggested the role of different environmental factors including nutritional factors in the pathogenesis of T1DM through direct and indirect destruction of $\beta$ cells by inducing autoimmunity. Indirect destruction by autoimmunity could be induced by molecular homology between $\beta$ cell antigens and different environmental factors or by perturbing the immune system to induce autoimmunity. The role of maternal diet and nutritional components has been investigated in many animal studies. These factors are considered as exogenous maternal factors in the pathogenesis of T1DM. It is essential to understand the role of different exogenous maternal factors in planning effective preventative strategies (33). Thus, in this study, we reviewed studies in the field, which mostly investigated the association of one or limited numbers of nutrients with T1DM.

\subsection{Food Groups}

Four studies investigated the association of the consumption of different food groups during pregnancy and lactation with T1DM or beta-cell autoimmunity. In the United States, Lamb et al. (23) for the first time evaluated the effect of maternal diet, including the use of vegetables, root vegetables, fruits, meat and poultry, fish, cow's milk and cow's dairy products, gluten-containing food, and non-gluten cereal grains during pregnancy on islet autoimmunity (IA) in offspring. They showed that maternal potato consumption during pregnancy delayed the onset of IA. However, they did not indicate any association between the other food groups and IA, and suggested that maternal diet during pregnancy could affect the development of IA in children (23).

Brekke et al. (25) in Sweden during the All Babies in Southeast Sweden (ABIS) study investigated the role of maternal diet composition in the incidence of IA in offspring. Maternal diet was evaluated using a 22-item food frequency questionnaire(FFQ). The findings demonstrated that less-than-daily consumption of coffee had a protective role in the development of IA, and that less-than-daily use of vegetables was associated with increased risk of IA (25).

Virtanen et al. (27) in their cohort study in Finland indicated that among 27 different food groups studied, only low-fat margarine, berries, and coffee were inversely associated with the development of advanced IA in offspring.

Muntoni et al. (19) in Italy studied the association between maternal nutritional factors during pregnancy and lactation with T1DM. They showed a significant association 
between children's meat consumption during early life and T1DM. However, they reported an insignificant association between maternal nutritional factors during pregnancy and lactation with T1DM. There was a trend of significance in the relationship between the maternal consumption of meat during pregnancy and lactation with T1DM (19).

Considering that few studies are available in the field and since the results of the mentioned studies are non-conclusive, further large-scale prospective studies are needed to elucidate the association between specific foods or food groups and the risk of T1DM.

\subsection{Vitamin D}

Vitamin D was the most frequently studied nutrient in our review. Stene et al. $(15,16)$, in their pilot study suggested that vitamin D supplement or cod liver oil consumption during pregnancy could reduce the risk of T1DM in children, but their nationwide study did not confirm the suggestion. Fronczak et al. (21) reported that only maternal vitamin D consumption via foods could delay the development of IA, whereas maternal vitamin D use via supplements did not have such an effect. Brekke et al. (22), in their cohort study in Sweden, indicated that the maternal use of vitamin D during pregnancy could only reduce the risk of T1DM and IA during the first year of lives. In another cohort study in Finland, Marjamaki et al. (26) did not show any association between maternal vitamin D consumption and T1DM. Findings of a recent large cohort study from Finland, Germany, Sweden, and the United States also did not report any significant association between vitamin D supplement consumption during pregnancy and the risk of IA (32).

A meta-analysis of observational studies in the field did not support the effectiveness of maternal vitamin D consumption in preventing T1DM (34). However, their results indicated that using vitamin D during early life had a supporting effect on T1DM. They included three studies in their meta-analysis to evaluate the association between maternal vitamin D intake during pregnancy and T1DM $(15,16$, 25 ). Given the findings of the reviewed studies, it appears that although several studies suggested that maternal vitamin D consumption during pregnancy could prevent IA, the results of the mentioned studies were inconclusive.

The association between vitamin D and the risk of T1DM appears to be highly complicated. Evidences suggest that the association is related not only to vitamin intake as well as dose and dietary habits, but also to some genetic factors including polymorphisms of vitamin D metabolic pathway genes such as vitamin D binding protein (VDBP), $1 \alpha$ hydroxylase (CYP27B1), vitamin D receptor (VDR), and vitamin D 25-hydroxylase (CYP2R1) (35). Thus, it is recom- mended to consider these factors in evaluating the role of vitamin D in the pathogenesis of T1DM. More studies are still needed to make more conclusive results in the field.

\subsection{Coffee}

Many studies have investigated the association of coffee consumption with T2DM, but not with T1DM $(35,36)$, which may be due to the different pathogenesis of the two diseases. In this review, four of the studies investigated the association between maternal coffee use and T1DM. In the first study conducted in 1994, Virtanen et al. (14) did not report any significant association between the two variables. Another study by the same author with a larger sample size indicated a protective effect of coffee against T1DM(27). Sandra et al., in a case-control study in Serbia, reported maternal coffee use during pregnancy as a risk factor for the development of T1DM (17). Another cohort study by Brekke et al. (25) demonstrated that less-than-daily use of coffee by mothers during pregnancy was rather protective against T1DM. Considering the findings of the reviewed studies, it is suggested that high coffee consumption could be associated with increased risk of T1DM, whereas low coffee consumption may have protective effects against T1DM. However, further studies are needed for a better understanding of the association between maternal coffee use and the risk of T1DM.

\subsection{Fatty Acids}

Evidence suggested that fatty acids could affect immune responses and inflammatory reactions and that maternal diet fatty acid content could affect the fatty acids content of breast milk and consequently its availability in infants and their offspring $(37,38)$. Some researchers studied the association of the maternal intake of fatty acids during pregnancy and lactation with the risk of T1DM in offspring $(18,21,28,29,32)$, but obtained controversial results. Most of the studies did not find any significant association between the maternal intake of different fatty acids including SFA, PUFA, and MUFA during pregnancy and lactation with T1DM or IA. Niinisto et al. (28) in Finland reported that the maternal intake of palmitic acid during pregnancy was associated with decreased risk of clinical T1DM. Accordingly, they observed that the intake of fat from fresh milk and low-fat margarine was associated with increased and decreased risk of preclinical T1DM, respectively. However, it appears that there are still controversies in the field, which could be resolved by further studies (28).

Based on the results of their animal studies, Kagohashi et al. (12) suggested that from studied maternal nutritional factors during pregnancy and lactation, the dietary n-6/n-3 EFA ratio had a role in the pathogenesis and clinical course of T1DM in offspring. 


\subsection{Meat}

Earlier studies did not show any significant association between the maternal consumption of meat during pregnancy and T1DM or IA. However, two recent studies in the field demonstrated that the maternal consumption of meat during pregnancy and lactation was a risk factor for T1DM $(19,29)$. Niinistö et al., in their cohort study in Finland, indicated that the total maternal consumption of meat during pregnancy increased the risk of both preclinical and clinical T1DM, with the risk being more prominent for processed meat products (29).

\subsection{Other Micronutrients and Vitamins}

Available documents indicated that using multivitamins and other supplements such as retinol, vitamin C, vitamin $\mathrm{E}$, beta-carotene, selenium, manganese, iron, and zinc had no protective effects against $\operatorname{T1DM}(15,20,23)$.

From the above evidence of the association between maternal nutrient components during pregnancy and lactation and the risk of T1DM, we conclude that although maternal diet could influence the development of IA and T1DM in offspring, there is no sufficient evidence for most nutrients and available data are controversial, which should be dealt with in future cohort or interventional studies.

The strength of this review was that no similar review study existed in this field and most of the selected papers were cohort or well-designed case-control studies. One limitation of the review was that the studies were not similar regarding methods, dietary components, and populations. Moreover, most of the cohort studies evaluated associations for IA.

\section{Conclusions}

This review indicates that the maternal consumption of some foods is associated with increased or decreased risk of T1DM. However, for some foods or dietary components, including coffee, vitamin $\mathrm{D}$, and fatty acids, the results are not conclusive. We conclude that although maternal diet could influence the development of IA and T1DM in offspring, there is no sufficient evidence for most nutrients and available data are controversial, which should be dealt with in future cohort or interventional studies. Further prospective studies are recommended to obtain more precise results in the field.

\section{Footnotes}

Authors' Contribution: All the authors, including SS, $\mathrm{MH}, \mathrm{AF}, \mathrm{SH}$, and RK. Contributed in all the steps of the work, including concept, design, and manuscript preparation.
The search and quality assessment were performed by SS and $\mathrm{SH}$. The main consultant was $\mathrm{MH}$. All the authors read and approved the manuscript.

Conflict of Interests: The authors have not conflict of interest.

Ethical Approval: The ethical approval code was IR.MUI.REC.1396.3.333.

Funding/Support: This study was supported by the Isfahan University of Medical Sciences under the research project number of 396333.

\section{References}

1. Katsarou A, Gudbjornsdottir S, Rawshani A, Dabelea D, Bonifacio E, Anderson BJ, et al. Type 1 diabetes mellitus. Nat Rev Dis Primers. 2017;3:17016. doi: 10.1038/nrdp.2017.16. [PubMed: 28358037].

2. Maahs DM, West NA, Lawrence JM, Mayer-Davis EJ. Epidemiology of type 1 diabetes. Endocrinol Metab Clin North Am. 2010;39(3):481-97. doi: 10.1016/j.ecl.2010.05.011. [PubMed: 20723815]. [PubMed Central: PMC2925303].

3. Butalia S, Kaplan GG, Khokhar B, Rabi DM. Environmental risk factors and type 1 diabetes: Past, present, and future. Can J Diabetes. 2016;40(6):586-93. doi: 10.1016/j.jcjd.2016.05.002. [PubMed: 27545597].

4. Masharani U, German M. Greenspan's basic \& clinical endocrinology. 8th ed. New York: McGraw-Hill Medical; 2007.

5. Eisenbarth GS. Type I diabetes mellitus. A chronic autoimmune disease. $N$ Engl $J$ Med. 1986;314(21):1360-8. doi: 10.1056/NEJM198605223142106. [PubMed: 3517648].

6. Rewers M, Ludvigsson J. Environmental risk factors for type 1 diabetes Lancet. 2016;387(10035):2340-8. doi: 10.1016/S0140-6736(16)30507-4 [PubMed: 27302273]. [PubMed Central: PMC5571740].

7. Bodin J, Stene LC, Nygaard UC. Can exposure to environmental chemicals increase the risk of diabetes type 1 development? Biomed Res Int. 2015;2015:208947. doi: 10.1155/2015/208947. [PubMed: 25883945] [PubMed Central: PMC4391693].

8. Capra L, Tezza G, Mazzei F, Boner AL. The origins of health and disease: The influence of maternal diseases and lifestyle during gestation. Ital J Pediatr. 2013;39:7. doi: 10.1186/1824-7288-39-7. [PubMed: 23343462]. [PubMed Central: PMC3599191].

9. Coppieters KT, Wiberg A, Tracy SM, von Herrath MG. Immunology in the clinic review series: Focus on type 1 diabetes and viruses: the role of viruses in type 1 diabetes: a difficult dilemma. Clin Exp Immunol. 2012;168(1):5-11. doi: 10.1111/j.1365-2249.2011.04554.x. [PubMed: 22385231]. [PubMed Central: PMC3390487].

10. Benson VS, Vanleeuwen JA, Taylor J, Somers GS, McKinney PA Van Til L. Type 1 diabetes mellitus and components in drinking water and diet: A population-based, case-control study in Prince Edward Island, Canada. J Am Coll Nutr. 2010;29(6):612-24. doi: 10.1080/07315724.2010.10719900. [PubMed: 21677125].

11. Winkler C, Mollenhauer U, Hummel S, Bonifacio E, Ziegler AG. Exposure to environmental factors in drinking water: risk of islet autoimmunity and type 1 diabetes-the BABYDIAB study. Horm Metab Res. 2008;40(8):566-71. doi: 10.1055/s-2008-1073165. [PubMed: 18500677].

12. Kagohashi Y, Otani $H$. Role of nutritional factors at the early life stages in the pathogenesis and clinical course of type 1 diabetes. Biomed Res Int. 2015;2015:382165. doi: 10.1155/2015/382165. [PubMed: 25883958]. [PubMed Central: PMC4391527].

13. Virtanen SM. Dietary factors in the development of type 1 diabetes. Pe diatr Diabetes. 2016;17 Suppl 22:49-55. doi: 10.1111/pedi.12341. [PubMed: 27411437]. 
14. Virtanen SM, Rasanen L, Aro A, Ylonen K, Lounamaa R, Akerblom HK, et al. Is children's or parents' coffee or tea consumption associated with the risk for type 1 diabetes mellitus in children? Childhood Diabetes in Finland Study Group. Eur J Clin Nutr. 1994;48(4):279-85. [PubMed: 8039488].

15. Stene LC, Ulriksen J, Magnus P, Joner G. Use of cod liver oil during pregnancy associated with lower risk of type I diabetes in the offspring. $\mathrm{Di}$ abetologia. 2000;43(9):1093-8. doi: 10.1007/s001250051499. [PubMed: $11043854]$.

16. Stene LC, Joner G; Norwegian Childhood Diabetes Study Group. Use of cod liver oil during the first year of life is associated with lower risk of childhood-onset type 1 diabetes: A large, populationbased, case-control study. Am J Clin Nutr. 2003;78(6):1128-34. doi: 10.1093/ajcn/78.6.1128. [PubMed: 14668274].

17. Sipetic SB, Vlajinac HD, Kocev NI, Marinkovic JM, Radmanovic SZ, Bjekic MD. The Belgrade childhood diabetes study: A multivariate analysis of risk determinants for diabetes. EurJPublic Health. 2005;15(2):11722. doi: 10.1093/eurpub/cki074. [PubMed: 15941756].

18. Sorensen IM, Joner G, Jenum PA, Eskild A, Torjesen PA, Stene LC. Maternal serum levels of 25-hydroxy-vitamin D during pregnancy and risk of type 1 diabetes in the offspring. Diabetes. 2012;61(1):1758. doi: 10.2337/db11-0875. [PubMed: 22124461]. [PubMed Central: PMC3237654].

19. Muntoni S, Mereu R, Atzori L, Mereu A, Galassi S, Corda S, et al. High meat consumption is associated with type 1 diabetes mellitus in a Sardinian case-control study. Acta Diabetol. 2013;50(5):713-9. doi: 10.1007/s00592-012-0385-2. [PubMed: 22391937].

20. Thorsen SU, Halldorsson TI, Bjerregaard AA, Olsen SF, Svensson J. Maternal and early life iron intake and risk of childhood type 1 diabetes: A Danish case-cohort study. Nutrients. 2019;11(4). doi: 10.3390/nu11040734. [PubMed: 30934897]. [PubMed Central: PMC6521102].

21. Fronczak CM, Barón AE, Chase HP, Ross C, Brady HL, Hoffman M, et al. In utero dietary exposures and risk of islet autoimmunity in children. Diabetes Care. 2003;26(12):3237-42. doi: 10.2337/diacare.26.12.3237. [PubMed:14633808].

22. Brekke HK, Ludvigsson J. Vitamin D supplementation and diabetesrelated autoimmunity in the ABIS study. Pediatr Diabetes. 2007;8(1):114. doi: 10.1111/j.1399-5448.2006.00223.x. [PubMed: 17341286].

23. Lamb MM, Myers MA, Barriga K, Zimmet PZ, Rewers M, Norris JM. Maternal diet during pregnancy and islet autoimmunity in offspring Pediatr Diabetes. 2008;9(2):135-41. doi: 10.1111/j.1399-5448.2007.00311.x. [PubMed: 18221424].

24. Uusitalo L, Kenward MG, Virtanen SM, Uusitalo U, Nevalainen J, Niinisto $S$, et al. Intake of antioxidant vitamins and trace elements during pregnancy and risk of advanced beta cell autoimmunity in the child. Am JClin Nutr. 2008;88(2):458-64. doi:10.1093/ajcn/88.2.458. [PubMed: 18689383].

25. Brekke HK, Ludvigsson J. Daily vegetable intake during pregnancy negatively associated to islet autoimmunity in the offspring-the ABIS study. Pediatr Diabetes. 2010;11(4):244-50. doi: 10.1111/j.13995448.2009.00563.x. [PubMed: 19761530].

26. Marjamaki L, Niinisto S, Kenward MG, Uusitalo L, Uusitalo U, Ovaskainen ML, et al. Maternal intake of vitamin D during pregnancy and risk of advanced beta cell autoimmunity and type 1 diabetes in offspring. Diabetologia. 2010;53(8):1599-607. doi: 10.1007/s00125-010-
1734-8. [PubMed: 20369220].

27. Virtanen SM, Uusitalo L, Kenward MG, Nevalainen J, Uusitalo U, Kronberg-Kippila C, et al. Maternal food consumption during pregnancy and risk of advanced beta-cell autoimmunity in the offspring. Pediatr Diabetes. 2011;12(2):95-9. doi: 10.1111/j.1399-5448.2010.00668.x. [PubMed: 21352426].

28. Niinisto S, Takkinen HM, Uusitalo L, Rautanen J, Nevalainen J, Kenward MG, et al. Maternal dietary fatty acid intake during pregnancy and the risk of preclinical and clinical type 1 diabetes in tADDIN EN.CITE.DATAhe offspring. Br J Nutr. 2014;111(5):895-903. doi: 10.1017/S0007114513003073. [PubMed: 24589042].

29. Niinisto S, Takkinen HM, Uusitalo L, Rautanen J, Vainio N, Ahonen S, et al. Maternal intake of fatty acids and their food sources during lactation and the risk of preclinical and clinical type 1 diabetes in the offspring. Acta Diabetol. 2015;52(4):763-72. doi: 10.1007/s00592-014-06730. [PubMed: 25563476].

30. Jacobsen R, Hypponen E, Sorensen TI, Vaag AA, Heitmann BL. Gestational and early infancy exposure to margarine fortified with vitamin D through a National Danish Programme and the risk of type 1 diabetes: The D-tect study. PLoS One. 2015;10(6). e0128631. doi: 10.1371/journal.pone.0128631. [PubMed: 26030061]. [PubMed Central: PMC4452099].

31. Antvorskov JC, Halldorsson TI, Josefsen K, Svensson J, Granstrom C, Roep BO, et al. Association between maternal gluten intake and type 1 diabetes in offspring: national prospective cohort study in Denmark. BMJ. 2018;362:k3547. doi: 10.1136/bmj.k3547. [PubMed: 30232082]. [PubMed Central: PMC6283375].

32. Silvis K, Aronsson CA, Liu X, Uusitalo U, Yang J, Tamura R, et al. Maternal dietary supplement use and development of islet autoimmunity in the offspring: TEDDY study. Pediatr Diabetes. 2019;20(1):8692. doi: 10.1111/pedi.12794. [PubMed: 30411443]. [PubMed Central: PMC6341488].

33. Paschou SA, Papadopoulou-Marketou N, Chrousos GP, KanakaGantenbein C. On type 1 diabetes mellitus pathogenesis. Endocr Connect. 2018;7(1):R38-46. doi: 10.1530/EC-17-0347. [PubMed: 29191919]. [PubMed Central: PMC5776665].

34. Dong JY, Zhang WG, Chen JJ, Zhang ZL, Han SF, Qin LQ. Vitamin $D$ intake and risk of type 1 diabetes: A meta-analysis of observational studies. Nutrients. 2013;5(9):3551-62. doi: 10.3390/nu5093551. [PubMed: 24036529]. [PubMed Central: PMC3798920].

35. Rak K, Bronkowska M. Immunomodulatory effect of vitamin D and its potential role in the prevention and treatment of type 1 diabetes mellitus-a narrative review. Molecules. 2018;24(1). doi: 10.3390/molecules24010053. [PubMed: 30586887]. [PubMed Central: PMC6337255].

36. Carlstrom M, Larsson SC. Coffee consumption and reduced risk of developing type 2 diabetes: A systematic review with meta-analysis. Nutr Rev. 2018;76(6):395-417. doi: 10.1093/nutrit/nuy014. [PubMed: 29590460].

37. Calder PC. n-3 fatty acids, inflammation and immunity: New mechanisms to explain old actions. Proc Nutr Soc. 2013;72(3):326-36. doi: 10.1017/S0029665113001031. [PubMed: 23668691]

38. Nishimura RY, Barbieiri P, Castro GS, Jordao AA, Jr, Perdona Gda S, Sartorelli DS. Dietary polyunsaturated fatty acid intake during late pregnancy affects fatty acid composition of mature breast milk. Nutrition. 2014;30(6):685-9. doi: 10.1016/j.nut.2013.11.002. [PubMed: 24613435]. 
Table 2. Details of the Finally Selected Cohort Studies

\begin{tabular}{|c|c|c|c|c|c|c|}
\hline & $\begin{array}{l}\text { Authors, Time, } \\
\text { Place }\end{array}$ & $\begin{array}{c}\text { Follow-Up } \\
\text { Period, y }\end{array}$ & Sample Size & Dietary Component & $\begin{array}{l}\text { Outcome } \\
\text { T1DM/IA }\end{array}$ & Findings \\
\hline $\mathbf{1}$ & $\begin{array}{l}\text { Fronczak et al., } \\
\text { 2003, USA (21) }\end{array}$ & 4 & $\begin{array}{l}233 \text { mothers and } \\
\text { their offspring }\end{array}$ & $\begin{array}{l}\text { omega-3 fatty acids, } \\
\text { omega- } 6 \text { fatty acids, } \\
\text { vitamin D as supplement, } \\
\text { vitamin D in foods }\end{array}$ & IA & $\begin{array}{l}\text { They indicated that vitamin D intake via foods } \\
\text { but not associated with lower risk of IA } \\
\text { development in their offspring (adjusted HR= } \\
0.37 \text {; } 95 \% \text { CI } 0.17-0.78 \text { ). They did not report any } \\
\text { significant association between omega- } 3 \text { and } \\
\text { omega- } 6 \text { fatty acids by pregnant women with } \\
\text { the risk of IA development in their children. }\end{array}$ \\
\hline 2 & $\begin{array}{l}\text { Brekke et al., 2007, } \\
\text { Sweden (22) }\end{array}$ & 2.5 & $\begin{array}{l}\text { Parents of } 11,081 \text { and } \\
8,805 \text { infants at } 1 \\
\text { and } 2.5 \text { years of age }\end{array}$ & Vitamin-D supplements & IA & $\begin{array}{l}\text { Use of Vitamin-D supplements by pregnant } \\
\text { women was only associated with lower risk of } \\
\text { IA at one year of age (OR: } 0.707, \mathrm{CI}: 0.520 \text { - } \\
0.962, \mathrm{P}=0.028)\end{array}$ \\
\hline 3 & $\begin{array}{l}\text { Lamb et al., 2008, } \\
\text { USA (23) }\end{array}$ & 4 & $\begin{array}{l}642 \text { mothers and } \\
\text { their newborns }\end{array}$ & $\begin{array}{l}\text { Potatoes, other root } \\
\text { vegetables, } \\
\text { gluten-containing foods, } \\
\text { non-gluten cereal grains, } \\
\text { cow's milk and cow's milk } \\
\text { products, fruits, } \\
\text { vegetables, meat and } \\
\text { poultry, and fish }\end{array}$ & IA & $\begin{array}{l}\text { They reported that higher maternal } \\
\text { consumption of potatoes could delay the } \\
\text { development of IA in their offspring (HR:0.49, } \\
\text { CI: } 0.28 \text { - } 0.87 \text { ). There was no significant } \\
\text { association between other food groups and } \\
\text { nutrients used by mothers during pregnancy } \\
\text { and IA onset in children. }\end{array}$ \\
\hline 4 & $\begin{array}{l}\text { Uusitalo et al., 2008, } \\
\text { Finland (24) }\end{array}$ & 4.4 & $\begin{array}{l}3730 \text { mothers and } \\
4,297 \text { children with } \\
\text { high genetic } \\
\text { susceptibility to } \\
\text { T1DM }\end{array}$ & $\begin{array}{l}\text { Consumption of selected } \\
\text { dietary antioxidants foods } \\
\text { during pregnancy } \\
\text { including vitamin C and E, } \\
\text { betacarotene, retinol, zinc, } \\
\text { selenium and manganese }\end{array}$ & IA & $\begin{array}{l}\text { The higher consumption of selected dietary } \\
\text { antioxidants including vitamin } \mathrm{C}[\mathrm{OR}=0.92 \\
(0.72,1.18)] \text { and } \mathrm{E}[\mathrm{OR}=1.10(0.55,2.20)] \text {, } \\
\text { betacarotene }[\mathrm{OR}=1.00(0.82,1.22)] \text {, retinol }[\mathrm{OR} \\
=0.97(0.79,1.21)] \text {, zinc }[\mathrm{OR}=1.01(0.44,2.34)] \text {, } \\
\text { selenium }[\mathrm{OR}=1.21(0.54,2.70)] \text { and manganese } \\
{[\mathrm{OR}=0.97(0.65,1.44)] \text { had no protective effect }} \\
\text { for advances IA onset in their offspring during } \\
\text { first years of life. }\end{array}$ \\
\hline 5 & $\begin{array}{l}\text { Brekke et al., 2010, } \\
\text { Sweden (25) }\end{array}$ & 5 & 5,724 mothers & $\begin{array}{l}\text { Food groups including } \\
\text { vegetables and potatoes ( } \mathrm{n} \\
=3 \text { items), fish ( } \mathrm{n}=3 \\
\text { items), eggs and meat ( } \mathrm{n}= \\
4 \text { items), dairy products( } \mathrm{n} \\
=2 \text { items), bread ( } \mathrm{n}=1 \\
\text { item), pas- } \\
\text { tries/chips/chocolate/candy } \\
\text { ( } \mathrm{n}=4 \text { items), field } \\
\text { mushrooms }(\mathrm{n}=1 \text { items), } \\
\text { coffee }(\mathrm{n}=1 \text { item) and } \\
\text { alcohol }(\mathrm{n}=1 \text { item). }\end{array}$ & IA & $\begin{array}{l}\text { Less consumption of vegetables ( } 3-5 \\
\text { times/week) in comparison with its daily use } \\
\text { was associated with higher risk of IA onset (OR: } \\
1.6395 \% \text { CL: } 1.20-2.17, \mathrm{P}=0.002 \text { ). Less } \\
\text { consumption of coffee in comparison with its } \\
\text { daily use was tended to associate with lower } \\
\text { risk of IA onset (P for trend }=0.014 \text { ). }\end{array}$ \\
\hline 6 & $\begin{array}{l}\text { Marjamaki et al., } \\
\text { 2010, Finland (26) }\end{array}$ & 4.3 & $\begin{array}{l}\text { Mothers of } 3,723 \\
\text { infants }\end{array}$ & $\begin{array}{l}\text { Vitamin D from food or } \\
\text { from supplements }\end{array}$ & IA & $\begin{array}{l}\text { Maternal use of vitamin D (as supplement or } \\
\text { via its containing foods) was not associated } \\
\text { with the risk of advanced IA onset or T1DM in } \\
\text { the Finnish offspring with high genetic } \\
\text { susceptibility to T1DM. }\end{array}$ \\
\hline 7 & $\begin{array}{l}\text { Virtanen et al., 2011, } \\
\text { Finland (27) }\end{array}$ & 4.4 & $\begin{array}{l}4,297 \text { infants with } \\
\text { high susceptibility } \\
\text { to T1DM and their } \\
\text { mothers }\end{array}$ & $\begin{array}{l}\text { Milk and milk products, } \\
\text { cereal products, dietary } \\
\text { fats, vegetables, roots and } \\
\text { potato, fruits, berries, fruit } \\
\text { and berry juices, chocolate } \\
\text { and sweets, alcoholic } \\
\text { drinks, tea, coffee }\end{array}$ & IA & $\begin{array}{l}\text { The low maternal consumption of low-fat } \\
\text { margarine (use vs. non-use } \mathrm{HR}=0.60,95 \% \mathrm{CI} \text { : } \\
0.38-0.93, \mathrm{P}=0.02 \text { ), coffee (highest quarter vs. } \\
\text { lowest } \mathrm{HR}=0.62,95 \% \mathrm{CI} \text { : } 0.40-0.97, \mathrm{P}=0.04 \text { ), } \\
\text { and berries (continuous variable } \mathrm{HR} 0.90,95 \% \\
\mathrm{CI} \text { : } 0.83-0.98, \mathrm{P}=0.02 \text { ) was associated with } \\
\text { increased risk of advanced IA development }\end{array}$ \\
\hline 8 & $\begin{array}{l}\text { Niinisto et al., 2014, } \\
\text { Finland (28) }\end{array}$ & $4-6$ & $\begin{array}{l}4,887 \text { children with } \\
\text { high susceptibility } \\
\text { to T1DM and their } \\
\text { mothers }\end{array}$ & $\begin{array}{l}\text { Food groups including } \\
\text { cow's milk products, fresh } \\
\text { milk, cheese, sour milk, } \\
\text { butter, and butter-oil } \\
\text { spreads, low-fat } \\
\text { margarines, high-fat } \\
\text { margarines, oil, red meat, } \\
\text { and meat products, } \\
\text { poultry, fatty fish, lean fish, } \\
\text { and fatty acids including } \\
\text { SFA, MUFA, and PUFA }\end{array}$ & IA/T1DM & $\begin{array}{l}\text { According to their findings, the use of foods } \\
\text { rich in palmitic acid (HR }=0.82, \text { CL: } 0.67-0.99) \text {, } \\
\text { low-fat margarine (HR }=0.67, \text { CL: } 0.49-0.92) \text {, } \\
\text { and cheese (HR }=0.52, \mathrm{CL}: 0.31-0.87) \text { by } \\
\text { pregnant women were associated with the } \\
\text { decreased risk of clinical type of T1DM. Using } \\
\text { foods such as sour milk products (HR=1.14, CL: } \\
1.02-1.28) \text {, proteins from sour milk (HR }=1.15 \text {, } \\
\text { CL: } 1.02-1.29) \text {, and fat from fresh milk (HR = } \\
1.43, \text { CL: } 1.04-1.96) \text { in pregnancy was associated } \\
\text { with higher risk of the preclinical form of } \\
\text { T1DM. They did not show any significant } \\
\text { association between the maternal } \\
\text { consumption of foods rich in fatty acids and } \\
\text { risk of development of T1DM in offspring. }\end{array}$ \\
\hline
\end{tabular}


9

Niinisto et al., 2015, Finland (29)
$7.5-7.7$ pairs
Fatty acids including SFA MUFA, PUFA, and foods

rich in fatty acids during the lactation period

\begin{tabular}{|c|c|c|c|c|c|}
\hline 10 & $\begin{array}{l}\text { Jacobsen et al., 2015, } \\
\text { Australia (30) }\end{array}$ & 15 & $\begin{array}{l}331,623 \text { neonates } \\
\text { born in Denmark } \\
(1983-1988)\end{array}$ & $\begin{array}{l}\text { Margarine fortified with } \\
\text { vitamin D }\end{array}$ & \\
\hline 11 & $\begin{array}{l}\text { Antvorskov et al., } \\
\text { 2018, Denmark (31) }\end{array}$ & 15.6 & $\begin{array}{l}67565 \text { pregnant } \\
\text { women and their } \\
\text { offspring }\end{array}$ & Foods containing gluten & T1DM \\
\hline 12 & $\begin{array}{l}\text { Silvis et al., 2018, } \\
\text { Finland, Germany, } \\
\text { Sweden, and the } \\
\text { United States (32) }\end{array}$ & 8.6 & $\begin{array}{l}8676 \text { children with } \\
\text { increased genetic } \\
\text { risk of IA and their } \\
\text { mothers }\end{array}$ & $\begin{array}{l}\text { Supplemental vitamin D } \\
\text { and n-3 FAs }\end{array}$ & IA \\
\hline
\end{tabular}

IA/T1DM They did not find any significant association between fatty acid intake during lactation and risk of T1DM development in their children. There was a significant association between mothers consumption of red meat and meat products and processed meat products during lactation and increased risk of clinical $(\mathrm{HR}=$ $1.27,95 \%$ CI: $1.06=1.52, \mathrm{P}=0.025)$ and preclinical $(\mathrm{HR}=1.19,95 \% \mathrm{CI}: 1.02-1.40, \mathrm{P}=$ $0.038)$ T1DM. Using of vegetable oils by mothers during lactation period was associated with increased risk of preclinical type of T1DM (HR = $1.21,95$ \% CI: $1.03-1.41, \mathrm{P}=0.023$ )

They did not find evidence regarding the effectiveness of exposure of low dose vitamin D by using fortified margarine during the gestational period on the risk of T1DM before 15 years of age.

High maternal gluten intake during pregnancy was associated with increased risk of T1DM (HR=1.31, 95\% CI:1.001-1.72). The risk doubled in women with highest gluten intake ( $\geq 20 \mathrm{~g} /$ day) against those with lowest gluten intake ( $<7 \mathrm{~g} /$ day).

The use of supplemental vitamin $\mathrm{D}(\mathrm{HR}=$ 1.11,95\% Cl: $0.94-1.31)$ and $n-3$ FAs $(\mathrm{HR}=1.19,95 \%$ CI: $0.98-1.45$ ) by mothers during pregnancy was not associated with the risk of IA.

Abbreviations: IA, insulin autoantibodies; HR, hazard ratio; CI, confidence interval; T1DM, type 1 diabetes mellitus. 